\title{
NMDA Receptor Plasticity in the Hypothalamic Paraventricular Nucleus Contributes to the Elevated Blood Pressure Produced by Angiotensin II
}

\author{
Michael J. Glass, ${ }^{1}$ Gang Wang, ${ }^{1}$ Christal G. Coleman, ${ }^{1}$ June Chan, ${ }^{1}$ Evgeny Ogorodnik, ${ }^{1}$ Tracey A. Van Kempen, ${ }^{1}$ \\ Teresa A. Milner, ${ }^{1,4} \mathbb{C}^{-}$cott D. Butler, ${ }^{2,3}$ Colin N. Young, ${ }^{3}$ Robin L. Davisson, ${ }^{2,3}$ Costantino Iadecola, ${ }^{1}$ \\ and $\odot$ Virginia M. Pickel ${ }^{1}$ \\ ${ }^{1}$ Feil Family Brain and Mind Research Institute and ${ }^{2}$ Department of Cell and Developmental Biology, Weill Cornell Medical College, New York, New York \\ 10065, ${ }^{3}$ Department of Biomedical Sciences, College of Veterinary Medicine, Cornell University, Ithaca, New York 14853, and ${ }^{4}$ Laboratory of \\ Neuroendocrinology, The Rockefeller University, New York, New York 10065
}

Hypertension induced by angiotensin II (Ang II) is associated with glutamate-dependent dysregulation of the hypothalamic paraventricular nucleus (PVN). Many forms of glutamate-dependent plasticity are mediated by NMDA receptor GluN1 subunit expression and the distribution of functional receptor to the plasma membrane of dendrites. Here, we use a combined ultrastructural and functional analysis to examine the relationship between PVN NMDA receptors and the blood pressure increase induced by chronic infusion of a low dose of Ang II. We report that the increase in blood pressure produced by a 2 week administration of a subpressor dose of Ang II results in an elevation in plasma membrane GluN1 in dendrites of PVN neurons in adult male mice. The functional implications of these observations are further demonstrated by the finding that GluN1 deletion in PVN neurons attenuated the Ang II-induced increases in blood pressure. These results indicate that NMDA receptor plasticity in PVN neurons significantly contributes to the elevated blood pressure mediated by Ang II.

Key words: gene deletion; gene therapy; hypertension; hypothalamus; synaptic plasticity

\section{Introduction}

Hypertension is a major risk factor for cardiovascular and cerebrovascular diseases (Faraco and Iadecola, 2013). Angiotensin II (Ang II) is a circulating hormone implicated in human hypertension (Marc and Llorens-Cortes, 2011), and administration of Ang II is a widely used experimental model of the hypertensive state (Romero and Reckelhoff, 1999). In a hypertensive paradigm induced by 2 week administration of a subpressor dose of Ang II (i.e., slow-pressor hypertension), the increase in blood pressure is critically dependent on circumventricular structures, including the subfornical organ (Young et al., 2012). The subfornical organ influences central cardiovascular networks by a monosynaptic glutamatergic projection to the hypothalamic paraventricular nucleus (PVN). The PVN, in turn, is an established central coordinator of neurohumoral activity and sympathetic outflow,

\footnotetext{
Received June 3, 2014; revised Feb. 23, 2015; accepted March 11, 2015.

Author contributions: M.J.G., R.L.D., C.I., and V.M.P. designed research; M.J.G., G.W., C.G.C., J.C., E.O., T.A.V.K., and S.D.B. performed research; M.J.G., G.W., C.N.Y., R.L.D., and V.M.P. analyzed data; M.J.G., G.W., T.A.M., C.N.Y., R.L.D., C.I., and V.M.P. wrote the paper.

This research was supported by the National Institutes of Health grants HLO9657 (C.I., V.M.P., M.J.G., R.L.D., and T.A.M.), NS89323 (C.I.), MH40342 (V.M.P.), DA04600 (V.M.P.), DA024030 (M.J.G.), HL098351 (T.A.M.), and HLO63887 (R.L.D.).

The authors declare no competing financial interests.

Correspondence should be addressed to Dr. Michael J. Glass, Feil Family Brain and Mind Research Institute, Weill Cornell Medical College, 407 East 61st Street, New York, NY 10065. E-mail: mjg2003@med.cornell.edu.

DOI:10.1523/JNEUROSCI.2301-14.2015

Copyright $\odot 2015$ the authors $\quad 0270-6474 / 15 / 359558-10 \$ 15.00 / 0$
}

which are both known to regulate cardiovascular homeostasis (Ferguson et al., 2008).

Glutamate can influence neural signaling and plasticity by acting at the NMDA receptor subtype (Hunt and Castillo, 2012), a heteromer formed by the essential NMDA GluN1 receptor subunit (GluN1) along with various GluN2 subunits (Dingledine et al., 1999). The PVN is populated by neurons that express NMDA receptor subunit genes (Herman et al., 2000; Eyigor et al., 2001) and proteins (Petralia et al., 1994). In addition, molecular (Li et al., 2003), biochemical (Li et al., 2012), and immunocytochemical (Coleman et al., 2010; Marques-Lopes et al., 2014) studies have shown that the expression of NMDA receptor subunits can be modified by changes in systemic arterial pressure. The activation of neuronal nitric oxide synthase (nNOS) and the resultant production of nitric oxide (NO) is a key transducer of NMDA receptor signaling and plasticity (Garthwaite, 2008) and is also involved in blood pressure regulation and neurogenic hypertension (Wang et al., 2013).

Alteration in the subcellular location of ionotropic glutamate receptors is implicated in various forms of neural plasticity (Petralia, 2012). A similar process may be involved in hypertension-related plasticity. However, it has not been established whether Ang II-mediated increases in blood pressure are associated with changes in the location of the essential GluN1 subunit in PVN neurons, including those expressing nNOS. 
Functional studies linking the NMDA receptor to blood pressure regulation have been largely limited to in vitro (Ye et al., 2012) and acute pharmacological models (Crestani et al., 2010; Li and Pan, 2010). Chronic pharmacological manipulation of PVN NMDA receptors is complicated by limitations of brain delivery of small molecules, which may lack specificity and have toxic actions (Low and Roland, 2004), and display complex intraparenchymal diffusion kinetics typical of many small molecules. Gene-targeting strategies can overcome many of these shortcomings, but have received little attention in studies of NMDA receptor involvement in hypertension.

In the present study, we examined the association between increased blood pressure and GluN1 plasticity in the PVN by a combination of immunoelectron microscopy and viral-mediated gene transfer in adult male mice treated with $14 \mathrm{~d}$ administration of a subpressor dose of Ang II.

\section{Materials and Methods}

\section{Animals}

Experimental protocols involving animals and their care were approved by the Institutional Animal Care and Use Committee at Weill Cornell Medical College and conformed to NIH guidelines. Adult (4-5 months) male wild-type C57BL/6 mice and floxed GluN1 (fGluN1) mice on a C57BL/6 background were used. As previously described (Glass et al., 2008), mice homozygous for the fGluN1 gene have a loxP site placed in the intron between exons 10 and 11 and a second site downstream after exon 22. The two loxP sequences flank a region of the GluN1 gene that encodes the four membrane domains and the entire C-terminal sequence of the polypeptide chain. As described previously (Capone et al., 2012; Coleman et al., 2013), mice were anesthetized with isoflurane and implanted subcutaneously with osmotic mini-pumps (Alzet; Durect) loaded with saline or Ang II $\left(600 \mathrm{ng} / \mathrm{kg}^{-1} / \mathrm{min}^{-1}\right)$.

\section{Electron microscopic immunolabeling in Ang II-treated mice}

Tail-cuff plethysmography. Since implantation of an arterial telemeter is incompatible with transcardial brain perfusion required for the highresolution immunocytochemical experiments, measurement of arterial blood pressure was monitored with a noninvasive tail-cuff sphygmomanometer in studies examining receptor localization (Glass et al., 2007). During each daily session, 10 systolic blood pressure measurements were recorded and averaged. Although tail-cuff plethysmography underestimates absolute blood pressure values (Gross and Luft, 2003), this does not compromise our experiments since relative comparisons are made within groups of animals. At day 14 of Ang II or vehicle administration blood pressure was measured, and mice were then killed in preparation for immunocytochemistry.

GluN1 and nNOS dual immunocytochemistry. The methods for tissue processing and dual labeling immunocytochemistry using immunoperoxidase and immunogold markers were performed as previously described (Beckerman and Glass, 2012). Following the last blood pressure recording, three saline and three Ang II-infused mice were perfused using $3.75 \%$ acrolein $/ 2 \%$ PFA in $0.1 \mathrm{M} \mathrm{PB}$. Sections through the PVN were collected in $\mathrm{PB}$ and treated with $1 \%$ sodium borohydride for $30 \mathrm{~min}$. The sections were cryoprotected and flash frozen in Freon and liquid nitrogen to enhance antibody penetration. Sections were incubated for $30 \mathrm{~min}$ in $0.5 \% \mathrm{BSA}$ to minimize nonspecific labeling, followed by $72 \mathrm{~h}$ incubation in a mixture consisting of mouse anti-nNOS (1:200; BD Biosciences) and rabbit anti-GluN1 antisera (1:100; Millipore). The specificity of these reagents has been previously described (Beckerman and Glass, 2012; Wang et al., 2012). Sections were then washed in TBS, pH 7.6; incubated in anti-mouse IgG conjugated to biotin; rinsed in TBS; and then incubated for $30 \mathrm{~min}$ in avidin-biotin-peroxidase complex (ABC; 1:100; Vectastain Elite Kit; Vector Laboratories) in TBS. The bound peroxidase was visualized by reaction for $6 \mathrm{~min}$ in a $0.2 \%$ solution of $\mathrm{DAB}$ and $0.003 \%$ hydrogen peroxide in TBS. Immunogold labeling of anti-GluN1 was performed as follows. A $2 \mathrm{~h}$ incubation in a 1:50 dilution of donkey anti rabbit conjugated to ultra small gold (Electron Microscopy Sciences) was followed by a $5.5 \mathrm{~min}$ silver intensification procedure using an IntenSE M kit (GE Biosciences). Sections were processed for electron microscopy by postfixing in $2 \%$ osmium tetroxide for $1 \mathrm{~h}$, followed by dehydration and embedment in epoxy resin (Embed 812; Electron Microscopy Sciences).

Electron microscopic analysis. Sections were examined using a Tecnai transmission electron microscope. Images were collected at a magnification of $13,500 \times$. Profiles containing GluN1 with or without nNOS immunoreactivity were classified as neuronal (soma, dendrites, axons, and terminals) or glial based on criteria described by Peters et al. (1991). Dendritic profiles contained regular microtubular arrays and were usually postsynaptic to axon terminal profiles. Criteria for field selection included good morphological preservation, the presence of immunolabeling in the field, and proximity to the tissue-plastic interface (i.e., the tissue surface) to avoid problems from differences in antibody penetration (Milner et al., 2011).

Electron micrographs of saline and Ang II-infused animals were analyzed for distribution of GluN1 silver-intensified gold using MCID Image Analysis software (InterFocus Imaging). GluN1-labeled dendrites with and without nNOS labeling were tallied with respect to the subcellular localization of the immunogold particle and cross-sectional area and perimeter of the dendrite. ANOVA between saline and Ang II data was performed using JMP software (SAS Institute). Data are presented as mean \pm SEM with $N$ as the number of counted profiles. A one-way ANOVA followed by Fisher's LSD post hoc test was used for statistical comparisons between treatment groups. Differences were considered statistically significant when $p \leq 0.05$.

Electron microscopic images. For preparation of figures, images were adjusted for contrast and brightness using Adobe Photoshop CS4 software and imported into Microsoft Office PowerPoint 2008 to add lettering and generate composite figures.

\section{Conditional knock out of GluN1 and measurement of the slow- pressor response to Ang II}

Viral vectors. To spatially and temporally delete the GluN1 gene, a specially engineered recombinant serotype 2 adeno-associated virus (rAAV; $\sim 4.7 \mathrm{~kb}$ ) expressing Cre recombinase (Cre) and a GFP reporter (rAAVCre) was used. The vector also includes a CMV promoter/enhancer, a multiple cloning site for insertion of the GFP-Cre coding sequences, and poly A sequences (South et al., 2003). The control vector (rAAV-GFP) does not express Cre. This virus was generously provided by Dr. Charles Inturrisi of Weill Cornell Medical College.

Virus administration. Under deep isoflurane anesthesia viral vectors were bilaterally administered to the PVN of adult male mice. Approximately 150-200 nl of rAAV-GFP-Cre or rAAV-GFP $\left(5 \times 10^{6}\right.$ viral particles per microliter) were injected into the PVN $0.8 \mathrm{~mm}$ posterior and $0.2 \mathrm{~mm}$ lateral to bregma, at a depth of $4.8 \mathrm{~mm}$ ventral to the surface of the skull (Paxinos and Franklin, 2000). Microinjections were made by interfacing Picospritzer II (General Valve) to a glass pipette (WPI) with a tip pulled to a diameter of $\sim 50 \mu \mathrm{m}$, via a pipette holder and plastic tubing. Injections were made over a $10 \mathrm{~min}$ interval. To prevent leakage, the pipette was left in place for an additional $10 \mathrm{~min}$. Bone wax was used to cover the bore hole, and the mice were allowed to recover in their home cages. At least $14 \mathrm{~d}$ were required for maximal gene deletion (Glass et al., 2008).

Radiotelemetry. Measurement of arterial blood pressure in mice with PVN GluN1 deletion was performed by radiotelemetry. As described previously (Zimmerman et al., 2004), mice were anesthetized with ketamine + xylazine intraperitoneally and instrumented with radiotelemetry devices. Blood pressure was recorded daily to monitor the effects of Ang II during the entire infusion period.

Light microscopic immunohistochemistry. Mice injected with viral vectors were killed by cervical dislocation, and the brains were removed and postfixed for $24 \mathrm{~h}$ in $4 \%$ paraformaldehyde in $\mathrm{PB}$ and then cryoprotected by immersion in $30 \%$ sucrose. Coronal sections $(20 \mu \mathrm{m})$ from the forebrain at the level of the PVN were cut with a cryostat. Tissue sections were treated with $1.0 \%$ sodium borohydride in $\mathrm{PB}$ and then washed in $\mathrm{PB}$. Sections were incubated for $30 \mathrm{~min}$ in $0.5 \%$ BSA to minimize nonspecific labeling, followed by $24 \mathrm{~h}$ or $48 \mathrm{~h}$ incubation in primary rabbit anti-GFP (1:1000; Invitrogen), mouse anti-NeuN antisera (1:1000; Invitrogen), or 
rabbit anti-GluN1 antisera (1:100; Millipore). Sections were then washed in TBS; incubated in anti-rabbit or anti-mouse IgG conjugated to biotin, respectively; rinsed in TBS; and then incubated for $30 \mathrm{~min}$ in ABC in TBS. The bound peroxidase was visualized by reaction for $6 \mathrm{~min}$ in $\mathrm{DAB}$ and $0.003 \%$ hydrogen peroxide in TBS. Sections were mounted in $0.05 \mathrm{M} \mathrm{PB}$, dehydrated, and coverslipped on glass slides. These sections were examined using a Nikon light microscope.

Nonradioactive in situ hybridization. The steps for processing whole brains for in situ hybridization were identical to those for immunohistochemistry as discussed above. For in situ hybridization, GluN1 gene expression was measured by use of a nonradioactive $2.2 \mathrm{~kb}$ antisense riboprobe whose DNA sequence was deleted by Cre-loxP recombination in fGluN1 mice. Slide-mounted cryostat-cut brain sections $(20 \mu \mathrm{m})$ from mice injected with viral vectors were incubated in $4 \%$ PFA (20 $\mathrm{min}$ ), washed in $1 \times \mathrm{PBS}$, incubated in Proteinase $\mathrm{K}$ ( $2 \mathrm{~min}$ ), and washed in $1 \times$ PBS. Sections were again incubated in $4 \%$ PFA ( $5 \mathrm{~min}$ ), washed in $1 \times \mathrm{PBS}$, incubated in $0.25 \%$ acetic anhydride in $0.1 \mathrm{M}$ triethanolamine (10 min), and washed in $2 \times$ saline sodium citrate (SSC). Next, sections were incubated for $2 \mathrm{~h}$ in prehybridization solution ( $50 \%$ formamide, 0.3 $\mathrm{M} \mathrm{NaCl}, 10 \mathrm{~mm}$ TBS, $1 \mathrm{~mm}$ EDTA, $500 \mu \mathrm{g} / \mathrm{ml}$ salmon sperm DNA, and $500 \mu \mathrm{g} / \mathrm{ml}$ yeast tRNA) at $65^{\circ} \mathrm{C}$ in a chamber containing towels moistened with $4 \times$ SSC and $50 \%$ formamide. After incubation, the prehybridization solution was drained off the slide onto an RNase-free towel. Then, sections were hybridized with DIG-labeled antisense or sense probes for GluN1 (1:1000) in hybridization solution $(50 \%$ formamide, $0.3 \mathrm{M} \mathrm{NaCl}$, 20 mм TBS, 5 mм EDTA, 10 mm sodium phosphate buffer, 10\% dextran sulfate, $1 \times$ Denhardt's solution, and $500 \mu \mathrm{g} / \mathrm{ml}$ yeast tRNA), coverslipped, and placed overnight in an oven heated to $65^{\circ} \mathrm{C}$. After incubation, the coverslips were removed and the hybridized brain sections were washed in $5 \times \mathrm{SSC}$ at $55^{\circ} \mathrm{C}$, followed by $2 \times$ SSC and $50 \%$ formamide at $65^{\circ} \mathrm{C}$ (20 min). Next, sections were incubated in RNase buffer at $37^{\circ} \mathrm{C}$, followed by $50 \mu \mathrm{g} / \mathrm{ml}$ RNase A solution ( $30 \mathrm{~min}$ ), and then RNase buffer. Sections were then washed sequentially in $2 \times$ SSC and $50 \%$ formamide at $65^{\circ} \mathrm{C}(20 \mathrm{~min}), 2 \times \mathrm{SSC}$, washing buffer (10 min), and blocking solution $(30 \mathrm{~min})$. Sections were subsequently incubated in primary antiDIG primary antisera conjugated to alkaline phosphatase (1:1000) for $2 \mathrm{~h}$, followed by washing buffer. The sections were then incubated in detection buffer, followed by the chromogen NBT/BCIP. After $\sim 16 \mathrm{~h}$, slides were rinsed in distilled water and dehydrated through a series of alcohols and xylene, then coverslipped in Permount.

Light microscopic cell counting. Cell counting was performed using relative optical density measurements via Microcomputer Imaging Device software (MCID; Imaging Research), as previously described (Glass et al., 2008). Briefly, mounted sections were viewed with a Nikon Microphot-FX microscope equipped with a digital CoolSNAP camera (Photometrics ). The light microscopic images were acquired through an interface between the camera and a Macintosh computer. Pixel intensitythresholding procedures were performed as per manufacturer's guidelines on four sections per animal. Electronic images were imported into MCID, which automatically calculates a relative threshold level for each image, then adjusted using an object-enhancement filter that maximizes the contrast between large objects and background. Cell counts were made in three to five rostrocaudal bilateral sections containing brain regions of interest, averaged, and analyzed by one-way or two-way ANOVA. Cell counts were also performed manually to verify the consistency of automated measurements.

Because of its relatively small volume and complex geometrical shape, rAAV microinjected into the PVN almost always extended beyond the specific limits of this nucleus. However, the predominant localization of the injections to this brain region was assured by the confinement of the majority of GFP-labeled cells, as determined by a visual screening, to the boundaries of the PVN as defined by the atlas of Paxinos and Franklin (2000).

NO detection. To assess the effect of GluN1 deletion on NMDAmediated NO production in the PVN in the absence of elevated blood pressure, isolated PVN cells (Coleman et al., 2010) were obtained from untreated mice that had received unilateral PVN microinjection of rAAV-GFP or rAAV-Cre. Cells were incubated with the NO-sensitive fluorescent dye 4-amino-5-methylamino-2', $7^{\prime}$-difluorofluorescein di-
Table 1. MAP is elevated in mice administered saline or Ang II over $14 \mathrm{~d}$

\begin{tabular}{|c|c|c|c|c|c|c|}
\hline & \multicolumn{2}{|l|}{ Day 1} & \multicolumn{2}{|l|}{ Day 7} & \multicolumn{2}{|l|}{ Day 14} \\
\hline & Saline & Ang II & Saline & Ang II & Saline & Ang II \\
\hline $\begin{array}{l}\text { MAP } \\
\triangle M A P\end{array}$ & $94.3 \pm 3$ & $96.6 \pm 3$ & $\begin{array}{l}86 \pm 3 \\
-8.3\end{array}$ & $\begin{array}{l}109.8 \pm 2^{* \#} \\
+13.2\end{array}$ & $\begin{array}{l}102 \pm 2 \\
+7.7\end{array}$ & $\begin{array}{l}114.9 \pm 3^{* \#} \\
+18.3\end{array}$ \\
\hline
\end{tabular}

Data are presented as mean \pm SEM. ${ }^{*} P<0.05$, Ang $\|$ days 7 and 14 relative to day $1 .{ }^{\#} P<0.05$, Ang $\|$ relative to saline.

acetate (DAF-FM; $5 \mu \mathrm{mol} / \mathrm{L}$; Invitrogen) for $30 \mathrm{~min}$, rinsed for $30 \mathrm{~min}$, and imaged using an inverted fluorescence microscope (Nikon) equipped with a CCD camera (Princeton Instruments). Time-resolved fluorescence was measured every $30 \mathrm{~s}$ with an exposure time of $200 \mathrm{~ms}$ using image-analysis software (IPLab; Scanalytics). For baseline measurements, NO-dependent fluorescence was expressed as relative fluorescence units (RFUs). Changes in NO signal induced by $100 \mu \mathrm{M}$ NMDA (Sigma) were expressed as the ratio Ft/Fo, where Fo is the baseline fluorescence before application of NMDA and $F t$ is the fluorescence in the same cell after application of NMDA (Coleman et al., 2010). In some experiments, PVN cells were pretreated with the nonselective NOS inhibitor L-NNA (Sigma; $100 \mu \mathrm{mol} / \mathrm{L}$ ). Data are presented as mean \pm SEM with $N$ as the number of neurons tested. A one-way or two-way ANOVA followed by Tukey's post hoc test was used for statistical comparisons between treatment groups. Differences were considered statistically significant when $p \leq 0.05$.

ROS detection. Production of ROS following GluN1 deletion in the absence of elevated blood pressure was assessed using dihydroethidium (DHE) in isolated PVN cells (Wang et al., 2006) obtained from untreated mice that had received unilateral microinjection of rAAV-GFP or rAAVCre. All isolated cells were incubated with DHE ( $1 \mu \mathrm{mol} / \mathrm{L}$; Invitrogen $)$ for $30 \mathrm{~min}$. The fluorescence intensity was measured using a Nikon Diaphot 300 inverted microscope equipped with a CCD camera (Princeton Instruments). Time-resolved fluorescence was measured every $30 \mathrm{~s}$ with an exposure time of $100 \mathrm{~ns}$ using image-analysis software (IPLab; Scanalytics). For baseline measurements, ROS-dependent fluorescence was expressed as RFUs. The increase in the ROS signal induced by $100 \mu \mathrm{M}$ NMDA was expressed as the ratio of Ft/Fo, where Fo is the baseline fluorescence before application of NMDA, and $F t$ is fluorescence in the same cell after application of NMDA (Wang et al., 2006). Recordings were started after stable baseline fluorescence readings were achieved. In some experiments, cells were pretreated with the NMDA receptor antagonist MK801 (10 $\mu \mathrm{mol} / \mathrm{L}$; Sigma), a polypeptide inhibitor of the NADPH oxidase gp91phox docking sequence (gp91-ds) [H]GGGGCSTRIRRQL[NH2] or scrambled gp91-ds (s-gp91-ds) [H]GGGGCLRITRQS$\mathrm{R}$ [NH2] (Rey et al., 2001) at $1 \mu \mathrm{mol} / \mathrm{L}$ (Bio-Synthesis). Time-control experiments in which NMDA was not perfused were performed in parallel to assure the stability of the preparation. A one-way or two-way ANOVA followed by Tukey's post hoc test was used for statistical comparisons between treatment groups. Differences were considered statistically significant when $p \leq 0.05$.

\section{Results}

Plasma membrane GluN1 density is increased in dendrites of PVN neurons from wild-type mice following Ang II-induced elevations in arterial blood pressure

To assess the effect of Ang II-mediated increases in blood pressure on GluN1 localization, saline $(N=3)$ or Ang II $(N=3)$ were administered for $14 \mathrm{~d}$ to male mice at 4-5 months old, an age when mice are past maturity, but not yet affected by senescence (Flurkey et al., 2007). Blood pressure was recorded at $3 \mathrm{~d}$ intervals. There was a significant effect of treatment $(F=24.2, p<$ $0.0001)$, time $(F=25.8, p<0.0001)$, and a significant treatment $\times$ time interaction $(F=9.5, p<0.0001)$ on mean arterial pressure (MAP) in these mice (Table 1 ).

Brains from both the saline and the Ang II-treated mice were first sectioned at the level of the PVN, and these sections were then immunocytochemically processed for dual labeling of 


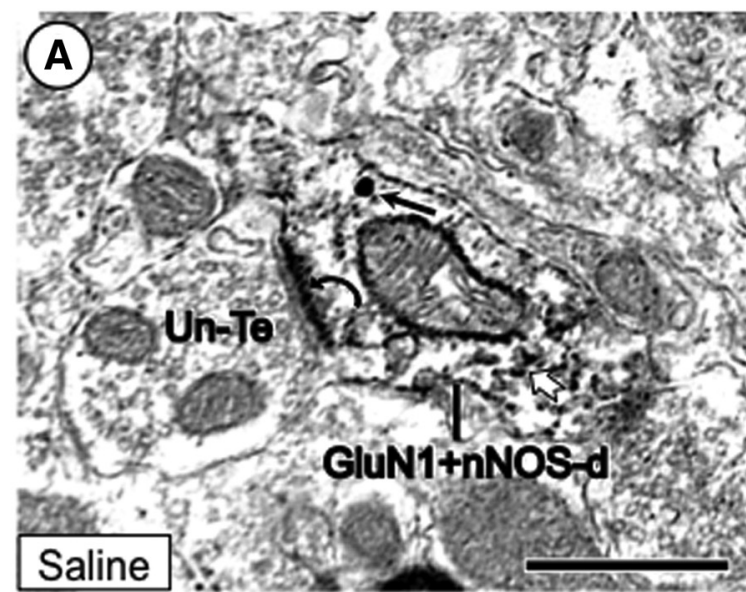

C Total GluN1

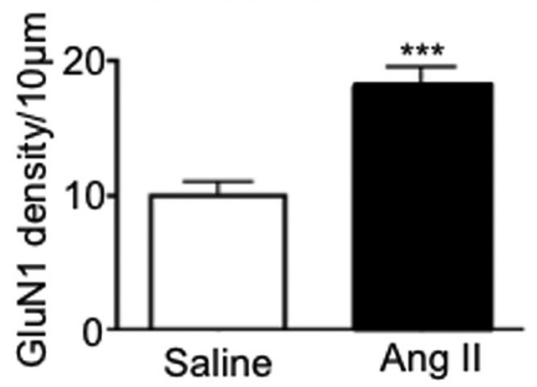

D Surface GluN1

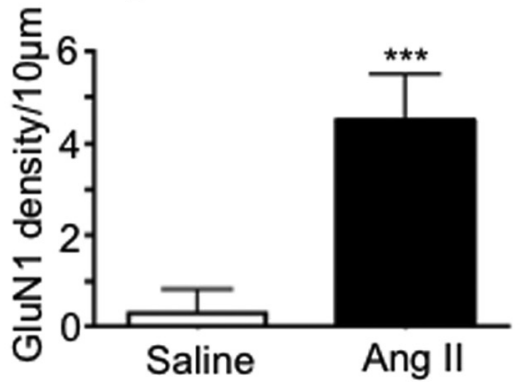

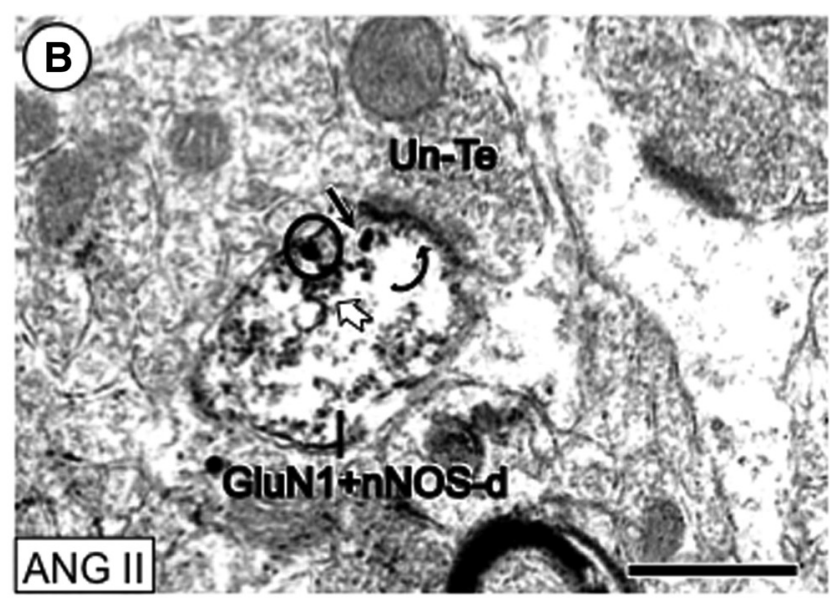

E Cytoplasmic GluN1

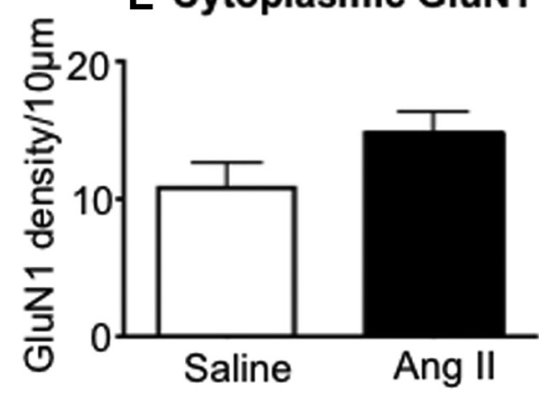

Figure 1. Mice with Ang Il-induced elevations in blood pressure show an increase in plasma membrane GluN1 in dendritic profiles also labeled for nNOS. Electron micrographs from the PVN of mice that received vehicle $(\boldsymbol{A})$ or Ang II $(\boldsymbol{B})$ showing silver-intensified immunogold labeling for GluN1 and immunoperoxidase reaction product for nNOS (white arrows) in dendritic profiles. Immunogold labeling for GluN1 is located in the cytoplasm (arrow) and near the surface (circles). Immunoperoxidase labeling for nNOS is diffuse throughout the cytoplasm or localized to endomembranes. There was a significantly higher density of total $(\boldsymbol{C})$ and surface $(\boldsymbol{D})$, but not cytoplasmic $(\boldsymbol{E})$, GluN1 labeling in dendritic profiles of PVN neurons in Ang II-treated animals compared with those administered saline. GluN1 + nNOS, dual-labeled dendrite; Un-Te, unlabeled terminal; curved arrow, asymmetric synapse. Data are presented as mean \pm SEM; ${ }^{* *} p<0.0001$. Scale bars, $500 \mathrm{~nm}$.

GluN1 and nNOS using immunogold-silver and immunoperoxidase markers, respectively. A qualitative visual analysis of the PVN from both saline and Ang II-infused animals revealed that a population of dendrites expressed immunoreactivity for both GluN1 and nNOS (Fig. 1 $A, B$ ). Dual-immunoreactive dendritic structures were frequently small to intermediate $\left(0.5-1.5 \mu \mathrm{m}^{2}\right)$ in size. The general pattern of GluN1 immunolabeling in subcellular compartments was similar in both groups of saline and Ang II-treated mice. Particles were affiliated with small vesicular organelles and were also found near the plasma membrane.

Dendrites are the main integrative unit of neurons and the major locus of synaptic plasticity (Sjöström et al., 2008). The spatial location of NMDA receptors in dendrites is an important factor in their signaling properties and the emergence of neuronal plasticity (Petralia, 2012). To examine the relationship between the increase in blood pressure and the subcellular location of GluN1 in dendrites of PVN neurons, a quantitative analysis was performed in a total of $13,500 \mu \mathrm{m}^{2}$ of tissue $\left(2250 \mu \mathrm{m}^{2} /\right.$ mouse $)$ from saline and Ang II-treated mice. Immunogold-silver particles were segregated into cytoplasmic and surface categories for the purpose of quantifying the density of labeling in each of these cellular compartments. In dual-labeled dendritic profiles, mice that had received Ang II showed significantly higher densities of total $\left(F_{(1,80)}=21.7, p<0.0001\right.$; Fig. $\left.1 C\right)$ and surface $\left(F_{(1,80)}=\right.$ $16.5, p<0.0001$; Fig. $1 D)$, but not cytoplasmic $\left(F_{(1,80)}=2.5, p>\right.$ 0.1 ; Fig. 1E), GluN1 labeling.
Another population of dendrites showed exclusive GluN1 labeling (Fig. 2A,B). Single-labeled dendritic profiles from vehicletreated mice were frequently small to intermediate $\left(0.5-1.5 \mu \mathrm{m}^{2}\right)$ in size. Visual analysis showed that immunogold particles were present in the cytoplasm as well as near the plasma membrane in these dendrites. In Ang II-administered mice, the general pattern of immunolabeling for both antigens was similar. However, there was an apparent increase in the number of surface gold-silver particles in mice receiving Ang II. Immunogold-silver particles were segregated into cytoplasmic and surface categories for the purposes of quantifying the density of labeling in each of these cellular compartments. Compared with vehicle-administered mice, animals that had received Ang II had a significantly higher density of total $\left(F_{(1,248)}=7.5, p<0.007\right.$; Fig. $\left.2 C\right)$ immunogold labeling in dendritic profiles exclusively labeled for GluN1. A significantly higher density of GluN1 surface labeling $\left(F_{(1,248)}=\right.$ 7.2, $p<0.008$; Fig. $2 D)$, but not cytoplasmic $\left(F_{(1,248)}=0.2, p>\right.$ 0.6; Fig. 2E) GluN1 was seen in Ang II-treated mice compared with those administered vehicle.

Plasma membrane receptors can be located at the postsynaptic density or at extrasynaptic sites distal to the synapse, and each population can transduce signals after ligand binding (Bard and Groc, 2011). To assess if the increase in surface GluN1 occurred to a similar extent in all plasma membrane locations, surface GluN1 labeling was segregated into synaptic (i.e., directly in contact with a synaptic junction) or extrasynaptic (i.e., not in contact 

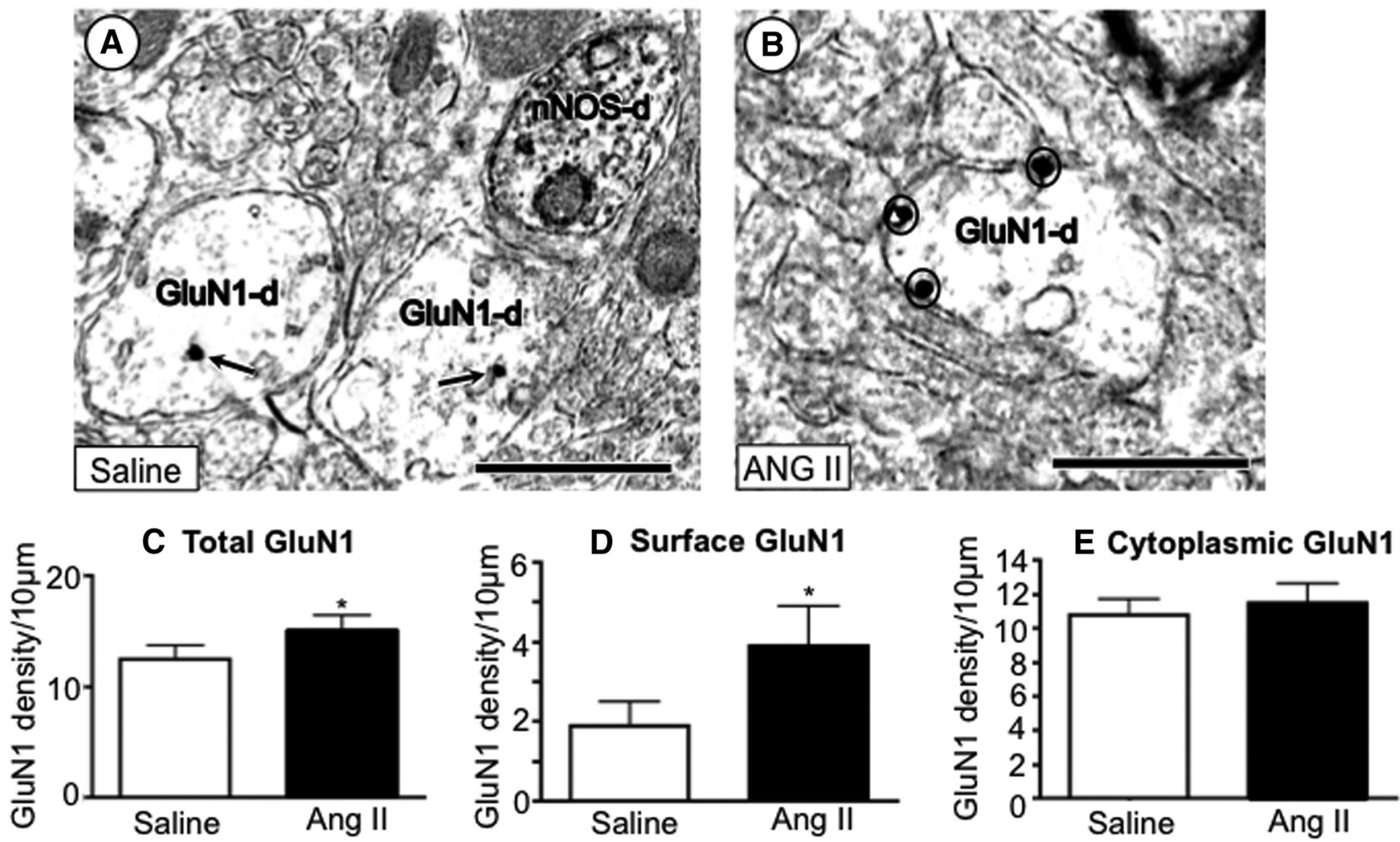

Figure 2. The Ang II-induced increase in blood pressure is associated with altered plasma membrane levels of GluN1 in single-labeled dendrites. Electron micrographs showing silver-intensified immunogold labeling for GluN1 in dendritic profiles from the PVN of mice that received vehicle ( $\boldsymbol{A}$ ) or Ang II (B). GluN1 labeling is prominently found in the cytoplasmic compartment (arrows) and the plasma membrane (circles). There was a significantly higher density (particles per unit area) of total $(\boldsymbol{C})$ and surface (D), but not cytoplasmic $(\boldsymbol{E})$, GluN1 labeling in mice administered Ang II compared with vehicle controls. nNOS-d, nNOS-labeled dendrite; GluN1-d, GluN1-labeled dendrite. Data are presented as mean \pm SEM; * $p<0.01$. Scale bars, $500 \mathrm{~nm}$.

with a synaptic apposition) categories. There was no treatmentdependent difference in the number of synaptic-affiliated GluN1 gold-silver particles (saline: $0.14 \pm 0.06$ vs Ang II: $0.11 \pm 0.05$ particles $/ 50 \mu \mathrm{m}^{2}$ of sampled tissue; $p>0.6$ ). However, there was a significant increase in extrasynaptic labeling in Ang II-treated mice compared with animals treated with vehicle (saline: $0.89 \pm$ 0.12 vs $1.2 \pm 0.09$ particles $/ 50 \mu \mathrm{m}^{2}$ of sampled tissue; $p<0.05$ ). The increase was found in dendrites exclusively labeled for GluN1 as well as those expressing GluN1 and nNOS.

In sum, mice with elevated blood pressure following chronic administration of a subpressor dose of Ang II showed an increase in extrasynaptic plasma membrane GluN1 in dendritic profiles of PVN neurons. This Ang II-induced change in the subcellular localization of GluN1 is consistent with a role for NMDA receptors in heightened extrasynaptic glutamate signaling during hypertension.

Unilateral microinjection of rAAV-Cre in the PVN of fGluN1 mice results in a reduction of local GluN1 expression and NMDA receptor-mediated signaling

Investigating the functional role of PVN NMDA receptors in Ang II-dependent increases in blood pressure requires the inhibition of receptors over the course of treatment. Conventional pharmacological NMDA receptor blockade can be hampered by the complex pharmacology of NMDA receptors (Svensson et al., 1991) and the potentially confounding effects of neural toxicity produced by receptor antagonists (Low and Roland, 2004). To overcome these challenges, we tested the feasibility of spatially and temporally deleting the obligatory GluN1 gene by local microinjection of rAAV-Cre into the PVN of fGluN1 mice. A control group received a microinjection of a non-Cre-expressing vector that expressed only the GFP reporter protein (rAAV-GFP). Immunoperoxidase labeling for GFP identified the sites of virally mediated gene transfer in the PVN after vector microinjection into the PVN (Fig. 3A). In situ hybridization (Fig. 3B) was used to determine GluN1 mRNA levels in injected and noninjected hemispheres following local vector administration. The number of neurons in each hemisphere following viral delivery was determined by immunolabeling for the neuronal marker NeuN (Fig. 3C).

Compared with mice that had received rAAV-GFP in the PVN, there was a reduction in GluN1 labeling (Fig. 3D) in rAAVCre-microinjected mice $\left(F_{(1,6)}=6.8, p<0.05\right)$. Expression of GluN1 was reduced $>50 \%(42.6 \pm 6.9$ vs $18 \pm 6$ cells per hemisphere), as was immunolabeling ( $42.3 \pm 10.1$ vs $16.5 \pm 12.4$ cells per hemisphere). There was no difference in the number of NeuN-labeled neurons (Fig. $3 E$ ) in the injected hemisphere in rAAV-GFP $(40.3 \pm 6.8$ cells per hemisphere $)$ and rAAV-Cre $(31.3 \pm 7.8$ cells per hemisphere $)$-treated mice $\left(F_{(1,6)}=0.3\right.$, $p>0.5)$.

Stimulation of NMDA receptors in the PVN has been shown to modulate the activity of nNOS (Coleman et al., 2010). To examine whether deleting the GluN1 receptor subunit reduces $\mathrm{NO}$ production, and to provide insight into the functional effect of GluN1 gene deletion in the PVN at the cellular level, NO production was measured following exposure to NMDA in dissociated cells from the PVN of fGluN1 mice microinjected with rAAV-Cre. Fluorescence microscopy for GFP and the NO-sensitive dye DAF-FM (Fig. 4A-D) established that PVN neurons with a 

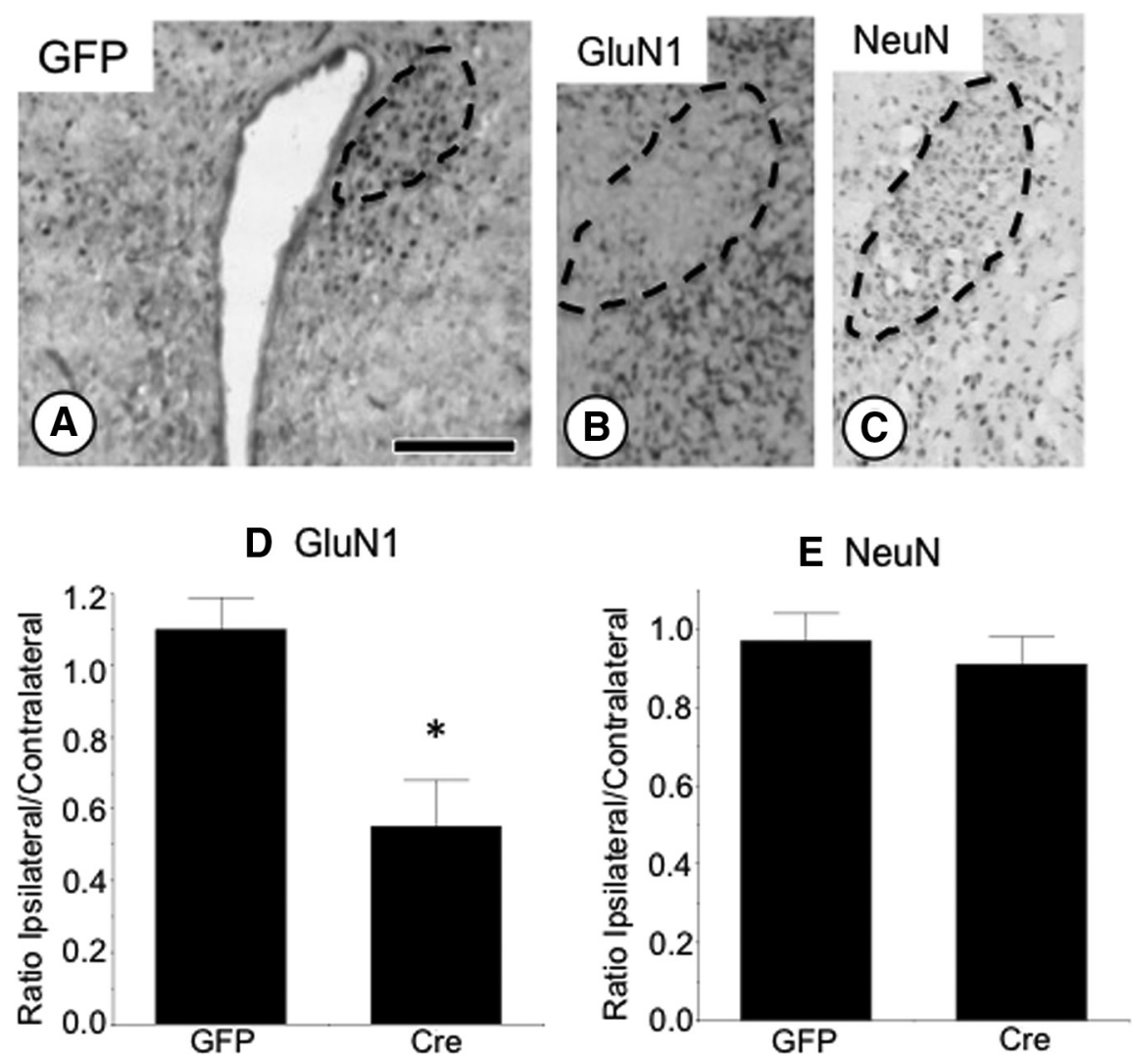

Figure 3. Microinjection of rAAV-Cre into the PVN of fGluN1 mice results in a decrease in GluN1 gene expression. Unilateral microinjection of rAAV-Cre in the PVN resulted in expression of the reporter protein GFP $(\boldsymbol{A})$ and reduced GluN1 mRNA levels $(\boldsymbol{B})$ in the injected area. Expression of the neuronal marker NeuN is shown in an adjacent section ( $\boldsymbol{C}$. There was a significant reduction in GluN1 $(\boldsymbol{D})$ but not NeuN $(\boldsymbol{E})$ labeling calculated as the ratio of the number of labeled cells ipsilateral and contralateral to the microinjection site; ${ }^{*} p<0.05$. Scale bars: $\boldsymbol{A}, 1 \mathrm{~mm} ; \boldsymbol{B}, \boldsymbol{C}, 0.5 \mathrm{~mm}$.

GluN1 deletion showed significantly lower NMDA-evoked NO production (Fig. 4E).

NADPH oxidase-generated ROS is also evoked by NMDA (Wang et al., 2013) and ROS has been shown to reduce NO availability by reacting to form peroxynitrite (Wang et al., 2012). As expected, NMDA-evoked ROS levels were significantly attenuated in isolated PVN cells from GluN1-deleted mice (Fig. $4 F$ ).

Both of the above findings are consistent with prior pharmacological results that NO (Wang et al., 2013) and ROS (Wang et al., 2013) production are critical for NMDA receptor-mediated currents assessed by single-cell physiology in a slice preparation. Although the present results provide strong evidence that GluN1 gene expression and functional NMDA receptors are critical for the activation of nNOS and NADPH oxidase in PVN cells, we will have to further verify this in the future. In summary, these data collectively indicate that microinjection of rAAV-Cre in the PVN of floxed mice locally deletes GluN1 and suppresses the NO and ROS production induced by NMDA in PVN neurons, attesting to the impact of GluN1 deletion on NMDA receptor signaling.

\section{Bilateral GluN1 deletion in the PVN attenuates the blood pressure elevation induced by Ang II}

To investigate the functional role of PVN NMDA receptors in the Ang II-mediated increase in blood pressure, fGluN1 mice underwent bilateral PVN-targeted delivery of rAAV-Cre or control rAAV-GFP 2 weeks before systemic Ang II infusion. As shown in Figure $5 A$, Ang II resulted in an elevation of blood pressure in the control vector-treated mice, whereas selective deletion of the
GluN1 subunit in the PVN blocked the blood pressure rise in Ang II-treated mice. During the latter half of Ang II treatment, a significant increase in mean arterial pressure was seen in the rAAV-GFPtargeted mice $(\Delta 18 \pm 6$; Fig. $5 B)$, whereas mean arterial pressure remained similar to baseline in the rAAV-Cre group $(\Delta 3 \pm$ 1; Fig. $5 B$ ). An example of GFP labeling in a mouse receiving bilateral $\mathrm{rAAV}-\mathrm{Cre}$ is presented in Figure 5C. Compared with rAAV-GFP-injected mice, those receiving rAAV-Cre in the PVN showed a $>55 \%$ reduction in the number of local GluN1immunolabeled cells $(42.2 \pm 4.7$ vs $18.7 \pm$ $\left.4.2 ; F_{(1,10)}=13.9, p<0.005\right)$. These results provide the first direct evidence that GluN1 gene expression, and presumably, functional PVN NMDA receptor activation, plays a critical role in Ang II-mediated hypertension.

\section{Discussion}

This study is the first to demonstrate that the increase in blood pressure induced by 2 week administration of a subpressor dose of Ang II is associated with an elevation in plasma membrane GluN1 in dendrites of nNOS-expressing PVN neurons. Further, the novel finding that GluN1 deletion in PVN neurons attenuates the Ang II-induced increases in blood pressure strengthens the functional implications of these observations. These results provide strong evidence that NMDA receptor plasticity in PVN neurons plays a role in the elevated blood pressure mediated by Ang II.

The subcellular distribution of GluN1 is modified in dendritic profiles of PVN neurons following increases in blood pressure induced by Ang II

We demonstrate that chronic low-dose Ang II infusion results in substantial changes in the subcellular distribution of GluN1 in the PVN of adult male mice. These results, however, contrast with prior studies done in younger animals. Recent sex and aging studies have investigated the relationship between the Ang II-dependent slowpressor response and the subcellular distribution of GluN1 in transgenic estrogen receptor or angiotensin receptor reporter mice. Following Ang II, there was no increase in plasma membrane GluN1 in estrogen receptor $\beta$ (Marques-Lopes et al., 2014) or angiotensin type $1 \mathrm{~A}$ receptor (Marques-Lopes et al., 2015)expressing dendrites of PVN neurons in 2-month-old male mice. In the present study, there was a significantly greater density of GluN1 near the plasma membrane of dendrites following the Ang II-mediated moderate pressor response in fully mature animals (4-5 months).These findings demonstrate different relationships between moderate increases in blood pressure and GluN1 localization in younger versus mature males, and suggest that the cellular substrates of PVN neuronal plasticity associated with elevated blood pressure may be age-dependent. Thus, the present study fills an important void in understanding the contribution of NMDA receptor plasticity in the PVN to the increase in blood pressure across the life span. 

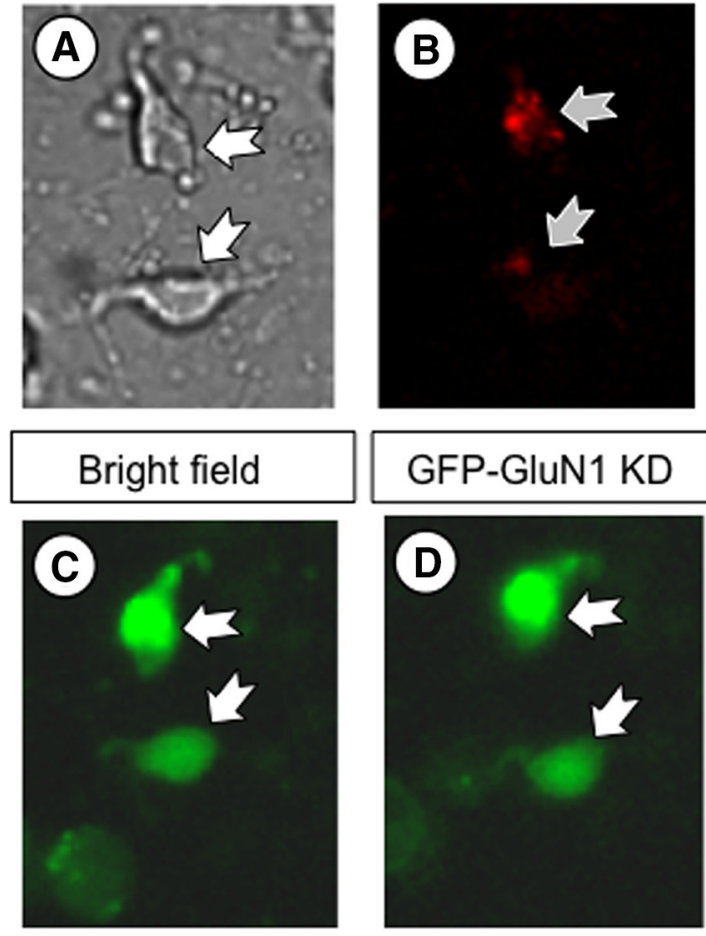

DAF-FM Control

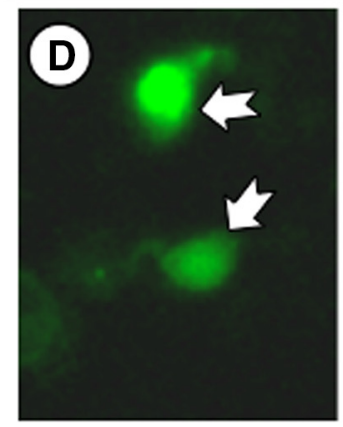

DAF-FM NMDA
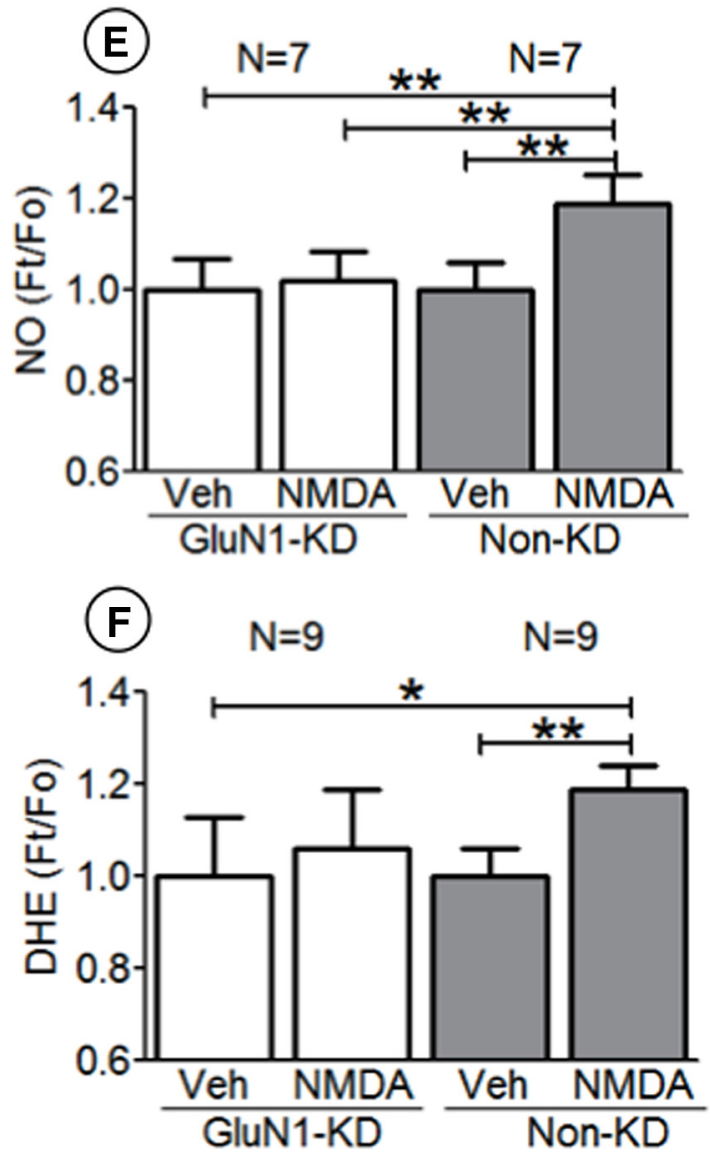

Figure 4. Deletion of GluN1 in PVN neurons suppresses NMDA receptor-mediated N0 and ROS production. Representative micrograph of dissociated PVN neurons $(\boldsymbol{A})$ obtained from a mouse that received unilateral $\mathrm{AAV}$-Cre in the PVN, demonstrating a reduction in GluN1 labeling $(\boldsymbol{B})$. The production of NO as measured by DAF-FM in these cells did not significantly differ
The presence of plasma membrane receptors identified by immunogold electron microscopy corresponds to sites of receptor binding (Boudin et al., 1998). In addition, the distribution of immunogold-labeled receptors shows the expected decrease in the ratio of surface-to-cytoplasmic localization in response to agonist stimulation (Haberstock-Debic et al., 2003). Therefore, it is likely that the distribution of protein as identified by immunogold electron microscopy reflects functional receptors. The increase in GluN1 was found predominantly near the extrasynaptic plasma membrane. Extrasynaptic receptors represent a pool of proteins that can be mobilized to the postsynaptic density upon synaptic activity (Bard and Groc, 2011). In addition, these proteins also respond to a ligand that diffuses outside the synapse, via neuronal or astrocytic release (Sanz-Clemente et al., 2013). The elevation of extrasynaptic GluN1 following the Ang II-induced pressor response is consistent with an increase in the number of potentially functional NMDA receptors that can be mobilized to the synapse and/or that are capable of responding to glutamate reaching beyond the synaptic junction during heightened activity via volume transmission (Sanz-Clemente et al., 2013). Although increases in extracellular glutamate (Qi et al., 2013; Jia et al., 2014; Kang et al., 2014) and excitatory signaling (Li et al., 2008) during experimental hypertension have been previously reported, the present results provide the first ultrastructural confirmation of elevated plasma membrane NMDA receptors in PVN neurons during the slow-pressor response to Ang II.

Within the PVN and other brain areas that participate in cardiovascular regulation, NMDA receptor activation is associated with the production of key intracellular signaling molecules that are known to be impacted by Ang II, including NO and ROS (Wang et al., 2013). The production of NO by nNOS in the PVN has been strongly implicated in blood pressure regulation (Wang and Golledge, 2013). In the present study, it was shown that following Ang II infusion, GluN1 is increased on the plasma membrane of dendrites that also expressed nNOS. These results suggest that the Ang II-dependent increase in blood pressure may be marked by altered NMDA receptor coupling to NO production in dendrites of PVN neurons.

The relationship between the Ang II-mediated slow-pressor response and the distribution of GluN1 in the PVN provides an interesting counterpoint to the increase in blood pressure seen with chronic intermittent hypoxia $(\mathrm{CIH})$, a model of obstructive sleep apnea that induces a slowly developing and chemosensorymediated increase in blood pressure (Prabhakar et al., 2012). Like Ang II, CIH has also been associated with an elevation of GluN1 in dendrites of PVN neurons (Coleman et al., 2010). However, in contrast to Ang II, which was associated with an increase in plasma membrane GluN1 in nNOS and non-nNOS-expressing dendrites, $\mathrm{CIH}$ was associated with an increase in cytosolic GluN1 in nNOS-expressing PVN neurons. Although the reason for the divergence in GluN1 distribution in Ang II versus CIHtreated mice is uncertain, it may be related to differences in several experimental parameters, including the mechanism by which the pressor response is induced in each paradigm and the time course of the increase in blood pressure induced by each treatment (Coleman et al., 2010; Wang et al., 2013). However, it is

$\longleftarrow$

between vehicle (Veh; $0 \mu \mathrm{m}$ NMDA) and $100 \mu \mathrm{M} \operatorname{NMDA}(\boldsymbol{C}-\boldsymbol{E})$, demonstrating that the GluN1 deletion attenuated NMDA-dependent NO production. Control cells (Non-KD) showed the expected increase in NMDA-mediated DAF-FM intensity $(\boldsymbol{E})$. There was also a reduction in NMDAmediated ROS production as measured by DHE staining; ${ }^{*} p<0.05$. Scale bar, $\boldsymbol{F}, 20 \mu \mathrm{m}$. 

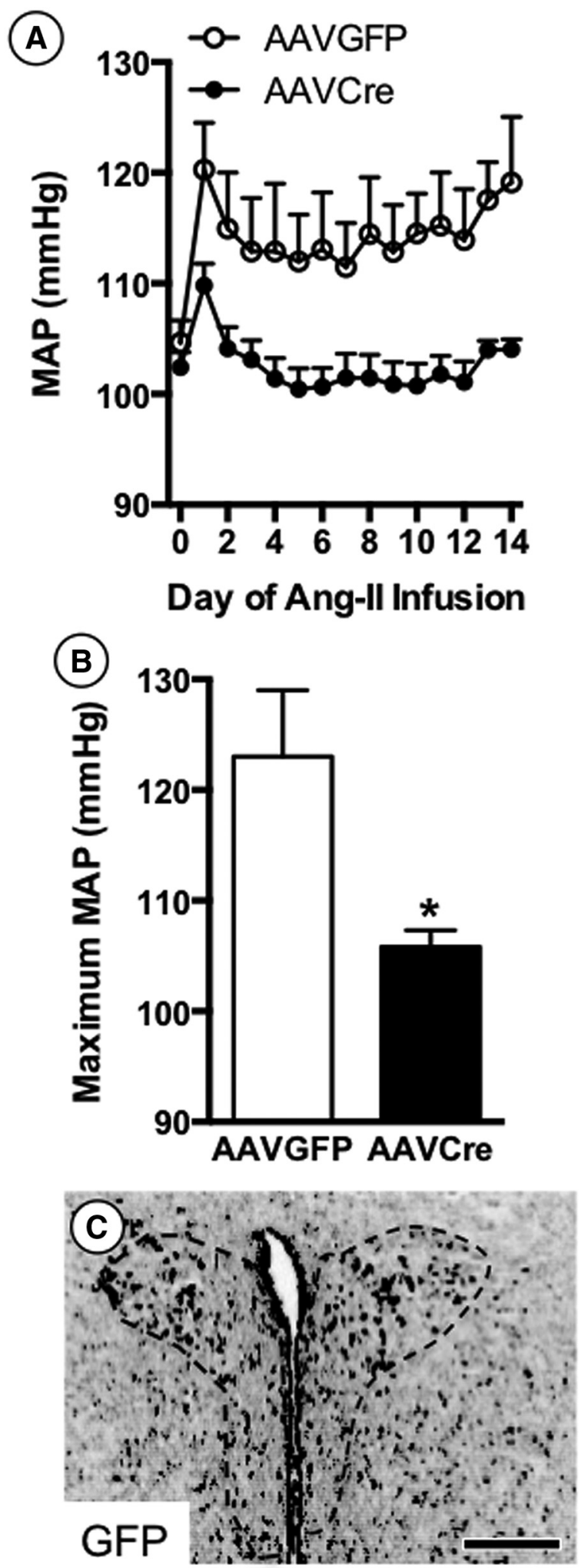

Figure 5. PVN GluN1 deletion results in a significant attenuation of Ang II-induced elevations in blood pressure. $A$, Daily radiotelemetry measurements of MAP during infusion of Ang II in fGluN1 mice microinjected with PVN-targeted AAV encoding Crerecombinase (rAAV-Cre) or control rAAV-GFP. $N=6-7 . B$, The maximum MAP occurred during days 7-14 of Ang II treatment. C, An example of labeling for the GFP reporter in a mouse that received bilateral $\mathrm{rAAV}$-Cre. The PVN is indicated by the areas bounded by the curved dashed figures; ${ }^{*} p<0.05$. Scale bar, $1 \mathrm{~mm}$. important to note that intracellular aggregations of receptors represent a reserve pool of protein capable of being mobilized to the plasma membrane (Bard and Groc, 2011) and, therefore, reflect a latent reservoir positioned for mobilization to the surface upon appropriate stimulation. The elevation in surface or cytoplasmic GluN1 seen with Ang II or hypoxia, respectively, both point to an increase in the pool of NMDA receptors in the major integrative compartment of neurons in response to diverse pressor treatments.

GluN1 gene expression in PVN neurons is required for the slow-pressor response to Ang II

Activation of the NMDA receptor in the PVN plays an important role in baroreceptive (Kubo et al., 1997), respiratory (Crestani et al., 2010), and sympathoexcitatory processes (Okada et al., 2000; Li et al., 2006) critical for blood pressure regulation. The activation of NMDA receptors in the PVN has also been implicated in the increased sympathetic output in response to neurogenic (Berrino et al., 1996), genetic (Ye et al., 2012), or physiological (Xu et al., 2012) treatments that induce elevations in blood pressure. Despite the molecular (Li et al., 2003), biochemical (Li et al., 2012), and immunocytochemical (Coleman et al., 2010) evidence implicating the NMDA receptor in blood pressure regulation, functional studies have been limited to in vitro (Ye et al., 2012) and/or acute pharmacological models (Crestani et al., 2010; Li and Pan, 2010).

Generally, studying the role of functional PVN neuronal NMDA receptors by conventional pharmacology is complicated by the uncertain specificity and potential toxicity (Low and Roland, 2004) of pharmacological receptor antagonists required for long-term CNS administration. In the present study, the essential GluN1 gene was deleted in PVN neurons by microinjection of a neurotropic rAAV-expressing Cre recombinase into the PVN of fGluN1 mice. This approach led to significant reductions in GluN1 gene expression, and also resulted in the attenuation of NMDA receptor-mediated intracellular signaling pathways involving $\mathrm{NO}$ and ROS production that are implicated in neural plasticity and the modulation of central cardiovascular regulatory pathways (Wang et al., 2013). In addition, PVN GluN1 deletion had important effects on cardiovascular function in vivo, as demonstrated by a significant reduction in the elevated blood pressure induced by Ang II. The present results are consistent with a growing literature showing the importance of PVN NMDA receptors in the potentiated sympathoexcitatory output associated with several different forms of hypertension (Xu et al., 2012; Ye et al., 2012).

\section{Functional considerations}

The increase in blood pressure induced by $14 \mathrm{~d}$ infusion of a subpressor dose of Ang II is known to result in a relatively modest rise in blood pressure in mice (Capone et al., 2011; Coleman et al., 2013; Marques-Lopes et al., 2014). This model also induces the typical structural and functional effects of hypertension in target organs, such as cardiac hypertrophy (Griffin et al., 1991) and vascular remodeling (Edgley et al., 2003) and endothelial (Capone et al., 2012) and neurovascular dysfunction (Capone et al., 2012), attesting to its validity as a model of hypertension (Romero and Reckelhoff, 1999). The present finding that functional PVN NMDA receptors play a critical role in the slow-pressor response to Ang II suggests that modulating PVN NMDA receptor expression, transport, or intracellular signaling cascades may offer some promise for translational developments in hypertension treatment (Mellone and Gardoni, 2013). 


\section{References}

Bard L, Groc L (2011) Glutamate receptor dynamics and protein interaction: lessons from the NMDA receptor. Mol Cell Neurosci 48:298-307. CrossRef Medline

Beckerman MA, Glass MJ (2012) The NMDA-NR1 receptor subunit and the mu-opioid receptor are expressed in somatodendritic compartments of central nucleus of the amygdala neurons projecting to the bed nucleus of the stria terminalis. Exp Neurol 234:112-126. CrossRef Medline

Berrino L, Pizzirusso A, Maione S, Vitagliano S, D’Amico M, Rossi F (1996) Hypothalamic paraventricular nucleus involvement in the pressor response to $\mathrm{N}$-methyl-d-aspartic acid in the periaqueductal grey matter. Naunyn Schmiedebergs Arch Pharmacol 353:157-160. CrossRef Medline

Boudin H, Pélaprat D, Rostène W, Pickel VM, Beaudet A (1998) Correlative ultrastructural distribution of neurotensin receptor proteins and binding sites in the rat substantia nigra. J Neurosci 18:8473-8484. Medline

Capone C, Faraco G, Park L, Cao X, Davisson RL, Iadecola C (2011) The cerebrovascular dysfunction induced by slow pressor doses of angiotensin II precedes the development of hypertension. Am J Physiol Heart Circ Physiol 300:H397-H407. CrossRef Medline

Capone C, Faraco G, Peterson JR, Coleman C, Anrather J, Milner TA, Pickel VM, Davisson RL, Iadecola C (2012) Central cardiovascular circuits contribute to the neurovascular dysfunction in angiotensin II hypertension. J Neurosci 32:4878-4886. CrossRef Medline

Coleman CG, Wang G, Park L, Anrather J, Delagrammatikas GJ, Chan J, Zhou J, Iadecola C, Pickel VM (2010) Chronic intermittent hypoxia induces NMDA receptor-dependent plasticity and suppresses nitric oxide signaling in the mouse hypothalamic paraventricular nucleus. J Neurosci 30:12103-12112. CrossRef Medline

Coleman CG, Wang G, Faraco G, Marques Lopes J, Waters EM, Milner TA, Iadecola C, Pickel VM (2013) Membrane trafficking of NADPH oxidase $\mathrm{p} 47$ (phox) in paraventricular hypothalamic neurons parallels local free radical production in angiotensin II slow-pressor hypertension. J Neurosci 33:4308-4316. CrossRef Medline

Crestani CC, Alves FH, Busnardo C, Resstel LB, Correa FM (2010) $\mathrm{N}$-methyl-D-aspartate glutamate receptors in the hypothalamic paraventricular nucleus modulate cardiac component of the baroreflex in unanesthetized rats. Neurosci Res 67:317-326. CrossRef Medline

Dingledine R, Borges K, Bowie D, Traynelis SF (1999) The glutamate receptor ion channels. Pharmacol Rev 51:7-61. Medline

Edgley AJ, Kett MM, Anderson WP (2003) Evidence for renal vascular remodeling in angiotensin II-induced hypertension. J Hypertens 21:14011406. CrossRef Medline

Eyigor O, Centers A, Jennes L (2001) Distribution of ionotropic glutamate receptor subunit mRNAs in the rat hypothalamus. J Comp Neurol 434: 101-124. CrossRef Medline

Faraco G, Iadecola C (2013) Hypertension: a harbinger of stroke and dementia. Hypertension 62:810-817. CrossRef Medline

Ferguson AV, Latchford KJ, Samson WK (2008) The paraventricular nucleus of the hypothalamus-a potential target for integrative treatment of autonomic dysfunction. Expert Opin Ther Targets 12:717-727. CrossRef Medline

Flurkey K, Currer JM, Harrison DE (2007) The Mouse in Aging Research. In: The mouse in biomedical research, Ed 2 (Fox JG et al., ed), pp 637672. Burlington, MA: American College Laboratory Animal Medicine.

Garthwaite J (2008) Concepts of neural nitric oxide-mediated transmission. Eur J Neurosci 27:2783-2802. CrossRef Medline

Glass MJ, Chan J, Frys KA, Oselkin M, Tarsitano MJ, Iadecola C, Pickel VM (2007) Changes in the subcellular distribution of NADPH Oxidase subunit p47phox in dendrites of rat dorsomedial nucleus tractus solitarius neurons in response to chronic administration of hypertensive agents. Exp Neurol 205:383-395. CrossRef Medline

Glass MJ, Hegarty DM, Oselkin M, Quimson L, South SM, Xu Q, Pickel VM, Inturrisi CE (2008) Conditional deletion of the NMDA-NR1 receptor subunit gene in the central nucleus of the amygdala inhibits naloxoneinduced conditioned place aversion in morphine dependent mice. Exp Neurol 213:57-70. CrossRef Medline

Griffin SA, Brown WC, MacPherson F, McGrath JC, Wilson VG, Korsgaard N, Mulvany MJ, Lever AF (1991) Angiotensin II causes vascular hypertrophy in part by a non-pressor mechanism. Hypertension 17:626-635. CrossRef Medline

Gross V, Luft FC (2003) Exercising restraint in measuring blood pressure in conscious mice. Hypertension 41:879-881. CrossRef Medline
Haberstock-Debic H, Wein M, Barrot M, Colago EE, Rahman Z, Neve RL, Pickel VM, Nestler EJ, von Zastrow M, Svingos AL (2003) Morphine acutely regulates opioid receptor trafficking selectively in dendrites of nucleus accumbens neurons. J Neurosci 23:4324-4332. Medline

Herman JP, Eyigor O, Ziegler DR, Jennes L (2000) Expression of ionotropic glutamate receptor subunit mRNAs in the hypothalamic paraventricular nucleus of the rat. J Comp Neurol 422:352-362. CrossRef Medline

Hunt DL, Castillo PE (2012) Synaptic plasticity of NMDA receptors: mechanisms and functional implications. Curr Opin Neurobiol 22:496-508. CrossRef Medline

Jia LL, Kang YM, Wang FX, Li HB, Zhang Y, Yu XJ, Qi J, Suo YP, Tian ZJ, Zhu Z, Zhu GQ, Qin DN (2014) Exercise training attenuates hypertension and cardiac hypertrophy by modulating neurotransmitters and cytokines in hypothalamic paraventricular nucleus. PLoS One 9:e85481. CrossRef Medline

Kang YM, Zhang DM, Yu XJ, Yang Q, Qi J, Su Q, Suo YP, Yue LY, Zhu GQ, Qin DN (2014) Chronic infusion of enalaprilat into hypothalamic paraventricular nucleus attenuates angiotensin II-induced hypertension and cardiac hypertrophy by restoring neurotransmitters and cytokines. Toxicol Appl Pharmacol 274:436-444. CrossRef Medline

Kubo T, Yanagihara Y, Yamaguchi H, Fukumori R (1997) Excitatory amino acid receptors in the paraventricular hypothalamic nucleus mediate pressor response induced by carotid body chemoreceptor stimulation in rats. Clin Exp Hypertens 19:1117-1134. CrossRef Medline

Li DP, Pan HL (2010) Increased group I metabotropic glutamate receptor activity in paraventricular nucleus supports elevated sympathetic vasomotor tone in hypertension. Am J Physiol Regul Integr Comp Physiol 299:R552-R561. CrossRef Medline

Li DP, Yang Q, Pan HM, Pan HL (2008) Pre- and postsynaptic plasticity underlying augmented glutamatergic inputs to hypothalamic presympathetic neurons in spontaneously hypertensive rats. J Physiol 586:16371647. CrossRef Medline

Li DP, Byan HS, Pan HL (2012) Switch to glutamate receptor 2-lacking AMPA receptors increases neuronal excitability in hypothalamus and sympathetic drive in hypertension. J Neurosci 32:372-380. CrossRef Medline

Li YF, Cornish KG, Patel KP (2003) Alteration of NMDA NR1 receptors within the paraventricular nucleus of hypothalamus in rats with heart failure. Circ Res 93:990-997. CrossRef Medline

Li YF, Jackson KL, Stern JE, Rabeler B, Patel KP (2006) Interaction between glutamate and GABA systems in the integration of sympathetic outflow by the paraventricular nucleus of the hypothalamus. Am J Physiol Heart Circ Physiol 291:H2847-H2856. CrossRef Medline

Low SJ, Roland CL (2004) Review of NMDA antagonist-induced neurotoxicity and implications for clinical development. Int J Clin Pharmacol Ther 42:1-14. CrossRef Medline

Marc Y, Llorens-Cortes C (2011) The role of the brain renin-angiotensin system in hypertension: implications for new treatment. Prog Neurobiol 95:89-103. CrossRef Medline

Marques-Lopes J, Van Kempen T, Waters EM, Pickel VM, Iadecola C, Milner TA (2014) Slow-pressor angiotensin II hypertension and concomitant dendritic NMDA receptor trafficking in estrogen receptor beta-containing neurons of the mouse hypothalamic paraventricular nucleus are sex and age dependent. J Comp Neurol 522:3075-3090. CrossRef Medline

Marques-Lopes J, Lynch MK, Van Kempen TA, Waters EM, Wang G, Iadecola C, Pickel VM, Milner TA (2015) Female protection from slowpressor effects of angiotensin II involves prevention of ROS production independent of NMDA receptor trafficking in hypothalamic neurons expressing angiotensin 1A receptors. Synapse 69:148-165. CrossRef Medline

Mellone M, Gardoni F (2013) Modulation of NMDA receptor at the synapse: promising therapeutic interventions in disorders of the nervous system. Eur J Pharmacol 719:75-83. CrossRef Medline

Milner TA, Waters EM, Robinson D, Pierce JP (2011) Degenerating processes identified by electron microscopic immunocytochemical methods. Methods Mol Biol 793:23-59. CrossRef Medline

Okada S, Murakami Y, Nishihara M, Yokotani K, Osumi Y (2000) Perfusion of the hypothalamic paraventricular nucleus with N-methyl-D-aspartate produces thromboxane $\mathrm{A} 2$ and centrally activates adrenomedullary outflow in rats. Neuroscience 96:585-590. CrossRef Medline

Paxinos G, Franklin KB (2000) The mouse brain in stereotaxic coordinates. San Diego, CA: Academic Press. 
Peters A, Palay S, Webster H (1991) The fine structure of the nervous system. New York: Oxford UP.

Petralia RS (2012) Distribution of extrasynaptic NMDA receptors on neurons. ScientificWorldJournal 2012:267120. CrossRef Medline

Petralia RS, Yokotani N, Wenthold RJ (1994) Light and electron microscope distribution of the NMDA receptor subunit NMDAR1 in the rat nervous system using a selective anti-peptide antibody. J Neurosci 14: 667-696. Medline

Prabhakar NR, Kumar GK, Peng YJ (2012) Sympatho-adrenal activation by chronic intermittent hypoxia. J Appl Physiol 113:1304-1310. CrossRef Medline

Qi J, Zhang DM, Suo YP, Song XA, Yu XJ, Elks C, Lin YX, Xu YY, Zang WJ, Zhu Z, Kang YM (2013) Renin-angiotensin system modulates neurotransmitters in the paraventricular nucleus and contributes to angiotensin II-induced hypertensive response. Cardiovasc Toxicol 13:48-54. CrossRef Medline

Rey FE, Cifuentes ME, Kiarash A, Quinn MT, Pagano PJ (2001) Novel competitive inhibitor of $\mathrm{NAD}(\mathrm{P}) \mathrm{H}$ oxidase assembly attenuates vascular $\mathrm{O}(2)(-)$ and systolic blood pressure in mice. Circ Res 89:408-414. CrossRef Medline

Romero JC, Reckelhoff JF (1999) State-of-the-Art lecture. Role of angiotensin and oxidative stress in essential hypertension. Hypertension 34: 943949. CrossRef Medline

Sanz-Clemente A, Nicoll RA, Roche KW (2013) Diversity in NMDA receptor composition: many regulators, many consequences. Neuroscientist 19:62-75. CrossRef Medline

Sjöström PJ, Rancz EA, Roth A, Häusser M (2008) Dendritic excitability and synaptic plasticity. Physiol Rev 88:769-840. CrossRef Medline

South SM, Kohno T, Kaspar BK, Hegarty D, Vissel B, Drake CT, Ohata M, Jenab S, Sailer AW, Malkmus S, Masuyama T, Horner P, Bogulavsky J, Gage FH, Yaksh TL, Woolf CJ, Heinemann SF, Inturrisi CE (2003) A conditional deletion of the NR1 subunit of the NMDA receptor in adult spinal cord dorsal horn reduces NMDA currents and injury-induced pain. J Neurosci 23:5031-5040. Medline

Svensson A, Pileblad E, Carlsson M (1991) A comparison between the noncompetitive NMDA antagonist dizocilpine (MK-801) and the competi- tive NMDA antagonist D-CPPene with regard to dopamine turnover and locomotor-stimulatory properties in mice. J Neural Transm Gen Sect 85:117-129. CrossRef Medline

Wang G, Anrather J, Glass MJ, Tarsitano MJ, Zhou P, Frys KA, Pickel VM, Iadecola C (2006) Nox2, Ca2+, and PKC play a role in Angiotensin II-induced free radical production in nucleus tractus solitarius. Hypertension 48:482-489. CrossRef Medline

Wang G, Coleman CG, Glass MJ, Zhou P, Yu Q, Park L, Anrather J, Pickel VM, Iadecola C (2012) Angiotensin II type 2 receptor-coupled nitric oxide production modulates free radical availability and voltage-gated Ca2 + currents in NTS neurons. Am J Physiol Regul Integr Comp Physiol 302:R1076-R1083. CrossRef Medline

Wang G, Coleman CG, Chan J, Faraco G, Marques-Lopes J, Milner TA, Guruju MR, Anrather J, Davisson RL, Iadecola C, Pickel VM (2013) Angiotensin II slow-pressor hypertension enhances NMDA currents and NOX2-dependent superoxide production in hypothalamic paraventricular neurons. Am J Physiol Regul Integr Comp Physiol 304:R1096-R1106. CrossRef Medline

Wang Y, Golledge J (2013) Neuronal nitric oxide synthase and sympathetic nerve activity in neurovascular and metabolic systems. Curr Neurovasc Res 10:81-89. CrossRef Medline

Xu B, Zheng H, Patel KP (2012) Enhanced activation of RVLM-projecting PVN neurons in rats with chronic heart failure. Am J Physiol Heart Circ Physiol 302:H1700-H1711. CrossRef Medline

Ye ZY, Li L, Li DP, Pan HL (2012) Casein kinase 2-mediated synaptic GluN2A up-regulation increases N-methyl-D-aspartate receptor activity and excitability of hypothalamic neurons in hypertension. J Biol Chem 287:17438-17446. CrossRef Medline

Young CN, Cao X, Guruju MR, Pierce JP, Morgan DA, Wang G, Iadecola C, Mark AL, Davisson RL (2012) ER stress in the brain subfornical organ mediates angiotensin-dependent hypertension. J Clin Invest 122:3960 3964. CrossRef Medline

Zimmerman MC, Lazartigues E, Sharma RV, Davisson RL (2004) Hypertension caused by angiotensin II infusion involves increased superoxide production in the central nervous system. Circ Res 95:210-216. CrossRef Medline 